\title{
PENGARUH SUHU, WAKTU, DAN KADAR AIR BAHAN BAKU TERHADAP PIROLISIS SERBUK PELEPAH KELAPA SAWIT
}

\section{EFFECT OF TEMPERATURE, TIME, AND WATER CONTENT OF RAW MATERIAL ON THE PYROLYSIS OF PALM MIDRIB POWDER}

\author{
Seri Maulina, Feni Sari Putri* \\ Departemen Teknik Kimia, Fakultas Teknik, Universitas Sumatera Utara \\ Jl. Almamater Kampus USU, Medan, 20155, Indonesia \\ *Email : fenisariputri@gmail.com
}

\begin{abstract}
Abstrak
Perkebunan kelapa sawit menghasilkan limbah berupa pelepah kelapa sawit dalam jumlah yang cukup besar. Salah satu cara untuk menangani dan meningkatkan nilai limbah pelepah kelapa sawit yang dihasilkan ini adalah dengan proses pirolisis. Pada penelitian ini digunakan bahan baku dalam bentuk serbuk dengan ukuran 32 - 50 mesh. Pengecilan ukuran bahan baku dapat meningkatkan laju pemanasan pada proses pirolisis. Tujuan dari penelitian ini adalah untuk mengetahui pengaruh suhu, waktu pirolisis dan kadar air bahan baku terhadap rendemen dan $\mathrm{pH}$ asap cair yang dihasilkan. Proses pirolisis dilakukan pada suhu $150{ }^{\circ} \mathrm{C}, 200{ }^{\circ} \mathrm{C}$, dan $250{ }^{\circ} \mathrm{C}$ dengan variasi waktu pirolisis 30 menit, 60 menit, dan 90 menit. Dari penelitian diketahui bahwa rendemen asap cair cenderung meningkat seiring naiknya suhu dan waktu pirolisis sampai pada kondisi dimana produksi gas yang sulit terkondensasi semakin banyak sehingga peningkatan suhu dan waktu pirolisis lebih lanjut akan menurunkan rendemen asap cair. Rendemen asap cair tertinggi diperoleh pada suhu pirolisis $250{ }^{\circ} \mathrm{C}$ selama 30 menit, yaitu sebesar $20,69 \%$. pH asap cair terbaik diperoleh dari asap cair hasil pirolisis pada suhu $250{ }^{\circ} \mathrm{C}$ selama 90 menit, yaitu 2,6.
\end{abstract}

Kata kunci : pelepah kelapa sawit, pirolisis, asap cair

\begin{abstract}
Palm plantation produce waste in form of palm midribs in large number. One of the way to handle and increase the value of palm midrib waste is by pyrolysis. The particle size of raw material that used in this study was 23 - 50 mesh. The reduction of raw material size can increase the heating rate of pyrolysis. This study aimed to analyze the effect of temperature, time, and water content of raw material on the yield and $\mathrm{pH}$ of liquid smoke. Pyrolysis of palm midrib powder was processed at 150 ${ }^{\circ} \mathrm{C}, 200{ }^{\circ} \mathrm{C}$, and $250{ }^{\circ} \mathrm{C}$ with various time was 30 minutes, 60 minutes, and 90 minutes. The study found that the yield of liquid smoke tend to increase with rising pyrolysis temperature and time until the condition when un-condensable gas was produced more so that the increase of pyrolysis temperature and time will further decrease the yield. The highest yield of liquid smoke obtained at $250^{\circ} \mathrm{C}$ for 30 minutes, is $20,69 \%$. The best $\mathrm{pH}$ of liquid smoke obtained at pyrolysis temperature 250 ${ }^{\circ} \mathrm{C}$ for 90 minutes, is 2,6 .
\end{abstract}

Keywords : palm midrib, pyrolysis, liquid smoke

\section{Pendahuluan}

Tanaman kelapa sawit saat ini tersebar di hampir seluruh provinsi di Indonesia. Pesatnya pertumbuhan perkebunan kelapa sawit berdampak pada jumlah limbah yang dihasilkan. Limbah padat dari perkebunan kelapa sawit dapat berasal dari pelepah sawit, tandan kosong kelapa sawit, cangkang kelapa sawit, dan sebagainya.

Limbah padat perkebunan kelapa sawit berupa pelepah sawit sejauh ini masih dimanfaatkan hanya sebagai pakan ternak. Pelepah sawit memiliki komposisi selulosa, hemiselulosa dan lignin berturut-turut sebesar $34,89 \%$, 27,14\%, dan $19,87 \%$ [16]. Dengan komposisi tersebut dan dengan jumlah pelepah yang dihasilkan cukup banyak, maka limbah pelepah sawit memiliki potensi yang besar untuk dimanfaatkan sebagai bahan baku pembuatan asap cair yang memiliki nilai ekonomis lebih tinggi. 
Asap cair terbentuk dari kondensasi asap melalui proses pirolisis konstituen kayu seperti selulosa, hemiselulosa dan lignin [18]. Kualitas asap cair hasil pirolisis ini tergantung pada bahan baku (jenis kayu), suhu pirolisis, ukuran partikel kayu, dan kadar air kayu [5, 15]. Ukuran partikel kayu yang lebih kecil memberikan laju yang lebih tinggi pada reaksi pirolisis cepat, tetapi partikel yang terlau kecil sulit untuk ditangani [13]. Oleh karena itu dilakukanlah penelitian ini untuk mengetahui pengaruh suhu dan waktu pirolisis serta kadar air bahan baku terhadap rendemen dan $\mathrm{pH}$ asap cair yang dihasilkan dari pirolisis serbuk pelepah kelapa sawit.

\section{Teori}

Pirolisis merupakan salah satu cara yang dapat digunakan untuk merubah biomassa menjadi produk yang bernilai ekonomis lebih tinggi [19]. Pirolisis adalah proses konversi termal dimana material diperlakukan dalam kondisi atmosfir inert tanpa adanya udara atau oksigen. Proses ini menghasilkan padatan char (charcoal, biochar), senyawa volatil yang dapat dikondensasikan (distilat), dan gas yang tak terkondensasi. Pirolisis dapat berlangsung lambat atau cepat tergantung pada prosesnya [1]. Pirolisis terjadi pada empat tahapan, dimulai dengan penguapan air, diikuti dengan dekomposisi hemiselulosa, selulosa dan lignin. Pirolisis hemiselulosa dan selulosa terjadi diantara $180{ }^{\circ} \mathrm{C}$ dan $350{ }^{\circ} \mathrm{C}$ dan menghasilkan asam karboksilat dan senyawa karbonil. Sementara lignin terpirolisis pada suhu diantara $300{ }^{\circ} \mathrm{C}$ dan $500{ }^{\circ} \mathrm{C}$ dan menghasilkan fenol. Pirolisis kayu sering menghasilkan senyawa yang tidak diinginkan seperti hidrokarbon polisiklik aromatik (HPA). Hidrokarbon polisiklik aromatik merupakan famili senyawa, beberapa diantaranya terbentuk secara alami, dan yang lainnya merupakan hasil dari pembakaran tak sempurna dan umumnya terbentuk pada suhu pirolisis antara $500{ }^{\circ} \mathrm{C}$ dan $900{ }^{\circ} \mathrm{C}$ [12].

Asap cair memiliki beragam manfaat sesuai grade nya. Asap cair grade 3 diorientasikan untuk pengawetan karet, pengganti asam semut, penyamakan kulit, menghilangkan jamur dan mengurangi bakteri patogen yang terdapat di kolam ikan. Asap cair grade 2 dapat digunakan sebagai pengawetan bahan makanan mentah seperti daging, termasuk daging unggas dan ikan. Sedangkan asap cair grade 1 dapat digunakan sebagai pengawet bahan makanan siap saji seperti mie basah, bakso, tahu dan sebagai penambah cita rasa pada makanan [17].

Pada penelitian ini digunakan pelepah kelapa sawit sebagai bahan baku. Pelepah kelapa sawit yang digunakan merupakan limbah pelepah yang di potong rutin sebelum panen dilakukan. Pelepah tersebut diperkecil ukurannya hingga berbentuk serbuk dengan ukuran 32 - 50 mesh. Pengecilan ukuran partikel bahan baku dapat meningkatkan laju pemanasan, sehingga waktu yang diperlukan untuk mendapatkan asap cair lebih singkat.

\section{Metodologi Penelitian}

Pelepah kelapa sawit yang digunakan sebagai bahan baku pada penelitian ini merupakan limbah pelepah kelapa sawit yang dipotong sebelum panen dilakukan. Pembuatan asap cair dilaksanakan di Laboratorium Proses Industri Kimia, Fakultas Teknik, Universitas Sumatera Utara. Sedangkan analisis rendemen dan $\mathrm{pH}$ asap cair dilaksanakan di Laboratorium Kimia Analisa, Fakultas Teknik, Universitas Sumatera Utara.

Alat yang digunakan untuk membuat asap cair yaitu rangkaian reaktor pirolisis dengan bahan bakar gas LPG. Sedangkan peralatan yang digunakan untuk analisis diantaranya adalah neraca analitik, $\mathrm{pH}$ meter, corong gelas, dan peralatan penunjang analisis lainnya.

Pelepah kelapa sawit terlebih dahulu diperkecil ukurannya kemudian dikeringkan dibawah sinar matahari langsung dan dengan bantuan pemanasan oven. Kemudian dihaluskan dengan ball mill dan diayak hingga diperoleh sampel dengan ukuran 32 - 50 mesh. Bahan baku yang digunakan untuk setiap proses pirolisis adalah 500 gram. Bahan baku di pirolisis pada suhu $150{ }^{\circ} \mathrm{C}, 200{ }^{\circ} \mathrm{C}$, dan $250{ }^{\circ} \mathrm{C}$ dengan waktu pirolisis 30 menit, 60 menit, dan 90 menit. Sebelum dipirolisis, terlebih dahulu dilakuakan analisis terhadap kadar air bahan baku dengan cara menimbang sebanyak 3 gram sampel di dalam cawan yang telah diketahui bobot konstannya, kemudian dipanaskan dengan oven pada suhu $110{ }^{\circ} \mathrm{C}$ selama 1 jam. Sampel tersebut dimasukkan ke desikator selama 15 menit, kemudian ditimbang beratnya. Pemanasan dan penimbangan dilakukan hingga didapat bobot konstan [11]. Kadar air bahan baku selanjutnya dihitung menggunakan Persamaan 1.

Kadar air $=\frac{\text { berat air }}{\text { berat sampel }} \times 100 \%$ 
Rendemen asap cair yang diperoleh dihitung dengan Persamaan 2 [7]. Selain itu juga dilakukan pengukuran $\mathrm{pH}$ terhadap asap cair yang dihasilkan.

Rendemen $=\frac{\text { berat asap cair }}{\text { berat bahan baku }} \times 100$

\section{Hasil dan Pembahasan}

Kadar air merupakan salah satu faktor yang mempengaruhi kualitas produk pirolisis yang dihasilkan. Kadar air bahan baku yang digunakan dapat mempengaruhi rendemen dan kualitas asap cair yang dihasilkan [5, 18]. Kadar air yang terlalu tinggi akan mengurangi kualitas asap cair karena akan menurunkan kadar produk yang dihasilkan, seperti kadar asam dan fenol [5]. Semakin tinggi kadar air bahan baku yang digunakan, maka kualitas asap cair yang dihasilkan akan menurun. Kadar air serbuk pelepah kelapa sawit yang digunakan sebagai bahan baku pembuatan asap cair dapat dilihat pada Tabel 1 .

Tabel 1. Kadar Air Serbuk Pelepah Kelapa Sawit Sebelum Pirolisis

\begin{tabular}{|c|c|c|}
\hline $\begin{array}{c}\text { Kadar air bahan } \\
\text { baku }(\%)\end{array}$ & $\begin{array}{l}\text { Waktu } \\
\text { pirolisis } \\
\text { (menit) }\end{array}$ & $\begin{array}{c}\text { Suhu } \\
\text { pirolisis } \\
\left({ }^{\circ} \mathrm{C}\right)\end{array}$ \\
\hline 12,23 & 30 & \multirow{3}{*}{150} \\
\hline 12,61 & 60 & \\
\hline 12,93 & 90 & \\
\hline 7,99 & 30 & \multirow{3}{*}{200} \\
\hline 7,83 & 60 & \\
\hline 7,30 & 90 & \\
\hline 7,98 & 30 & \multirow{3}{*}{250} \\
\hline 7,59 & 60 & \\
\hline 7,18 & 90 & \\
\hline
\end{tabular}

\section{Analisis Rendemen Asap Cair}

Analisis rendemen asap cair dilakukan untuk melihat seberapa banyak asap cair yang dihasilkan selama proses pirolisis. Rendemen asap cair dihitung dengan membandingkan berat asap cair yang diperoleh dengan bahan baku yang digunakan. Hasil analisis rendemen asap cair dapat dilihat pada Gambar 1.

Pada Gambar 1 terlihat bahwa rendemen asap cair cenderung mengalami peningkatan seiring dengan bertambahnya suhu pirolisis. Hal ini disebabkan pada suhu yang tinggi dekomposisi bahan baku akan lebih sempurna sehingga menghasilkan rendemen asap cair yang lebih tinggi pula [7]. Namun, pada variasi waktu di suhu $250{ }^{\circ} \mathrm{C}$ terjadi penurunan rendemen. Hal ini disebabkan pada peningkatan suhu pirolisis lebih lanjut dan melebihi batas akan memecah ikatan polimer semakin kuat sehingga menghasilkan ikatan-ikatan yang lebih kecil, sehingga produk yang dihasilkan lebih banyak dalam bentuk gas yang sulit terkondensasi seperti $\mathrm{CO}_{2}, \mathrm{CO}, \mathrm{H}_{2}$, dan $\mathrm{CH}_{4}$ dan menurunkan yield produk cair [2, 4, 9, 13]. Hal ini sesuai dengan hasil penelitian yang telah dilakukan sebelumnya terhadap asap cair hasil pirolisis tempurung kelapa pada rentang suhu $150-450{ }^{\circ} \mathrm{C}$, yang menunjukkan bahwa rendemen asap cair tertinggi diperoleh pada suhu $150-200{ }^{\circ} \mathrm{C}$ dan berkurang seiring meningkatnya suhu dimana rendemen asap cair terendah diperoleh pada suhu pirolisis $350-450$ ${ }^{\circ} \mathrm{C}[10]$.

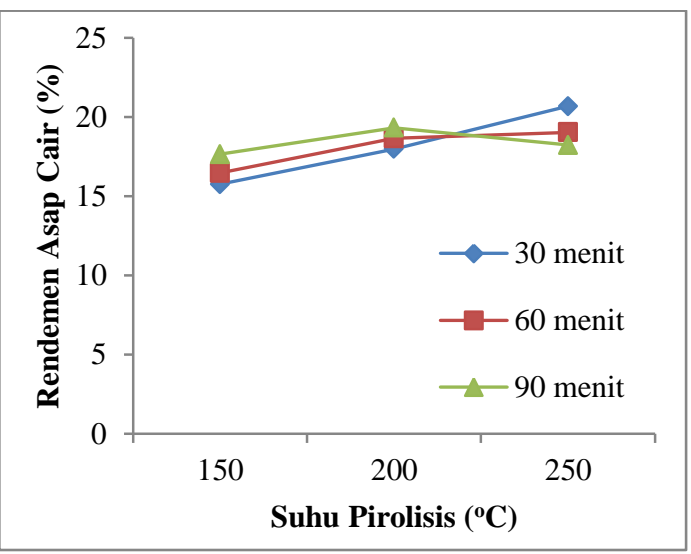

Gambar 1. Pengaruh suhu dan waktu pirolisis terhadap rendemen asap cair

Faktor yang mempengaruhi rendemen asap cair selain suhu pirolisis adalah waktu pirolisis $[5,15]$. Pada penelitian ini diperoleh rendemen asap cair cenderung meningkat seiring bertambahnya waktu pirolisis. Hal ini disebabkan semakin lama waktu pirolisis, semakin banyak bahan baku yang terdekomposisi akibat lamanya waktu kontak panas dengan bahan baku [8]. Namun juga didapatkan data rendemen yang menurun seiring bertambahnya waktu yaitu pada suhu pirolisis $250{ }^{\circ} \mathrm{C}$. Terjadinya penurunan rendemen disebabkan karena pada suhu yang tinggi dan waktu yang lama akan menyebabkan kehilangan bobot (loss) yang semakin besar. Kehilangan bobot (loss) semakin besar terjadi karena suhu air di dalam kondensor meningkat 
yang menyebabkan asap yang dihasilkan tidak terkondensasi secara optimal $[3,6]$.

Pada literatur lainnya juga disebutkan bahwa rendemen dan kualitas asap cair dipengaruhi oleh kadar air bahan baku $[5,18]$. Pengaruh kadar air terhadap rendemen asap cair dapat dilihat pada Gambar 2.

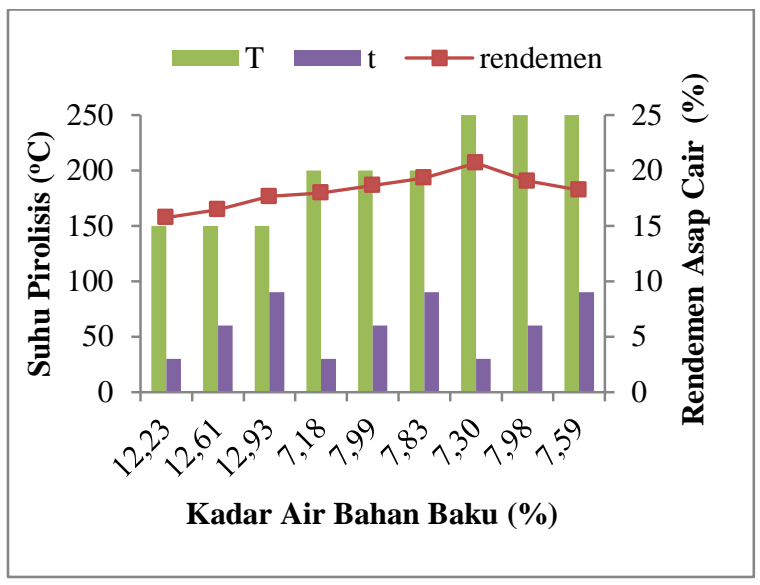

Gambar 2. Pengaruh kadar air bahan baku terhadap rendemen asap cair

Kadar air yang tinggi akan menghasilkan asap cair yang lebih banyak, tetapi akan mengurangi kualitas asap cair yang diproduksi karena tercampurnya hasil kondensasi uap air dengan asap cair yang dihasilkan sehingga menurunkan kadar asam [5]. Pada penelitian ini diperoleh rendemen asap cair yang dihasilkan pada suhu pirolisis $150{ }^{\circ} \mathrm{C}$ lebih kecil dibandingkan rendemen asap cair yang dihasilkan pada suhu $200{ }^{\circ} \mathrm{C}$ dan $250{ }^{\circ} \mathrm{C}$ meskipun kadar air bahan baku yang digunakan untuk pirolisis pada suhu $150{ }^{\circ} \mathrm{C}$ lebih besar. Hal ini disebabkan pada suhu yang lebih rendah masih sedikit dari komponen bahan baku yang terdekomposisi. Dari hasil penelitian secara keseluruhan dapat diketahui bahwa suhu pirolisis merupakan faktor yang lebih berpengaruh terhadap rendemen asap cair yang dihasilkan dibandingkan dengan kadar air bahan baku.

Pada penelitian ini rendemen asap cair tertinggi diperoleh dari proses pirolisis pada suhu $250{ }^{\circ} \mathrm{C}$ selama 30 menit yaitu sebesar $20,69 \%$. Sedangkan rendemen terendah, yaitu $15,77 \%$ diperoleh pada proses pirolisis suhu $150{ }^{\circ} \mathrm{C}$ selama 30 menit.

\section{Analisis pH Asap Cair}

Pengukuran $\mathrm{pH}$ asap cair dilakukan dengan menggunakan $\mathrm{pH}$ meter. Hasil pengukuran $\mathrm{pH}$ asap cair dapat dilihat pada Gambar 3.

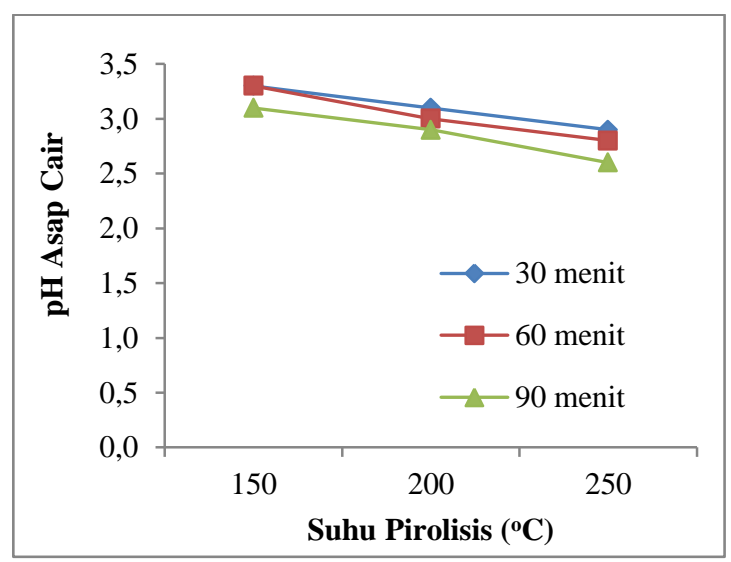

Gambar 3. Pengaruh suhu dan waktu pirolisis terhadap pH asap cair

Pada Gambar 3 dapat dilihat bahwa $\mathrm{pH}$ tertinggi asap cair diperoleh pada proses pirolisis dengan suhu $150{ }^{\circ} \mathrm{C}$ dan waktu pirolisis 30 menit, yaitu sebesar 3,3. Sedangkan $\mathrm{pH}$ terendah diperoleh pada asap cair hasil pirolisis pada suhu $250{ }^{\circ} \mathrm{C}$ selama 90 menit, yaitu sebesar 2,6. Dari hasil penelitian yang telah dilakukan diketahui peningkatan suhu dan waktu pirolisis akan menyebabkan $\mathrm{pH}$ asap cair yang dihasilkan menjadi lebih rendah. Hal ini disebabkan semakin tingginya suhu dan lamanya waktu pirolisis, konversi selulosa, hemiselulosa dan lignin yang ada di dalam bahan baku menjadi lebih besar sehingga menghasilkan senyawa asam dan fenol yang lebih banyak. Tingginya kandungan asam dan fenol dalam asap cair akan menyebabkan nilai $\mathrm{pH}$ semakin kecil.

Pada Gambar 4 dapat dilihat bahwa $\mathrm{pH}$ asap cair yang diperoleh akan menurun seiring berkurangnya kadar air bahan baku. Hal ini disebabkan pada kadar air bahan baku yang kecil kandungan asam dalam asap cair semakin banyak karena uap air yang ikut terkondensasi sedikit. Banyaknya senyawa asam dalam asap cair akan menyebabkan $\mathrm{pH}$ asap cair semakin rendah. 


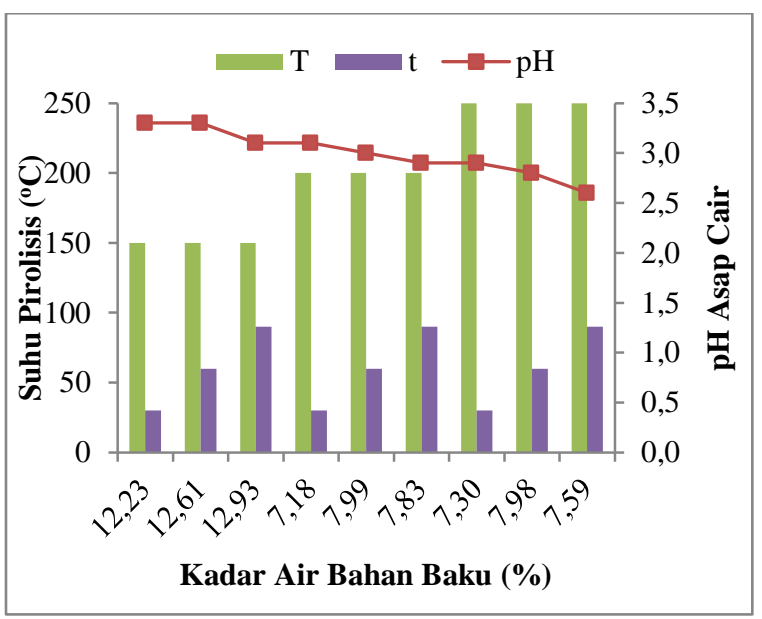

Gambar 4. Pengaruh kadar air bahan baku terhadap pH asap cair

Nilai $\mathrm{pH}$ yang terkandung dalam asap cair dipengaruhi oleh adanya kandungan senyawa asam, yaitu asam asetat dan asam-asam lainnya. Selain itu, kadar fenol juga mempengaruhi nilai pH karena karakter asam yang dimiliki fenol memiliki pengaruh pada cincin aromatis. Hasil pengukuran $\mathrm{pH}$ asap cair yang diperoleh dari cangkang kelapa adalah 1,41 , serat 2,62 , jerami padi 3,36, dan tongkol jagung 2,47 [18]. Hasil penelitian terhadap asap cair yang diperoleh dari pirolisis cangkang buah karet menghasilkan $\mathrm{pH}$ sebesar 2,497 pada suhu pirolisis $200{ }^{\circ} \mathrm{C}$ selama 1 jam. Asap cair yang bagus memiliki $\mathrm{pH}$ berkisar antara $1,5-3,7$, karena pada kondisi $\mathrm{pH}$ rendah ini spora mikroba tidak dapat hidup dan berkembang biak sehingga dapat menghambat pertumbuhan mikroba [14]. Semakin rendah $\mathrm{pH}$ yang dimiliki asap cair, maka kualitas asap cair tersebut semakin bagus karena memiliki kemampuan untuk menghambat pertumbuhan mikroba yang lebih besar.

\section{Kesimpulan}

Suhu dan waktu pirolisis mempengaruhi rendemen dan $\mathrm{pH}$ asap cair yang dihasilkan. Kenaikan suhu dan waktu akan meningkatkan rendemen asap cair sampai kondisi dimana produksi gas yang sulit terkondensasi semakin banyak sehingga peningkatan suhu dan waktu lebih lanjut akan menurunkan rendemen asap cair. Peningkatan suhu dan waktu akan menyebabkan asap cair yang dihasilkan memiliki $\mathrm{pH}$ semakin rendah. Rendemen asap cair tertinggi yaitu 20,69\% diperoleh melalui pirolisis pada suhu $250{ }^{\circ} \mathrm{C}$ selama 30 menit. Asap cair dengan $\mathrm{pH}$ terendah yaitu 2,6 diperoleh pada kondisi pirolisis suhu $250{ }^{\circ} \mathrm{C}$ selama 90 menit.

\section{Daftar Pustaka}

[1] A. Bridgwater, Fast Pyrolysis of Biomass for The Production of Liquids, Aston University, 2013.

[2] A. Rahmalinda dan Zutiniar, Studi Komparasi Karakteristik Asap Cair Hasil Pirolisis dari Kulit Durian, Pelepah dan Tandan Kosong Sawit dengan Pemurnian Secara Distilasi, Universitas Riau, 2010.

[3] A.G. Haji, Komponen Kimia Asap Cair Hasil Pirolisis Limbah Padat Kelapa Sawit, Jurnal Rekayasa Kimia dan Lingkungan, 9 : 109-116, 2013.

[4] C. Christine, S. Thomas, dan S. Varghese, Synthesis of Petroleum-Based fuel From Waste Plastics and Performance Analysis in a CI Engine, Journal of Energy. 2013.

[5] D.L. Ayudiarti dan R.N. Sari, Asap Cair dan Aplikasinya Pada Produk Perikanan, Squalen, $5: 3,2010$.

[6] H. Fadillah dan A. Alfiarty, The Influence Of Pyrolysis Temperature and Time To The Yield And Quality of Rubber Fruit Shell Liquid Smoke, Prosiding Seminar Nasional Teknik Kimia Pengembangan Teknologi Kimia untuk Pengolahan Sumber Daya Alam Indonesia, ISSN 1693-4393, 2015.

[7] I. Marasabessy, Produksi Asap cair dari Limbah Pertanian dan Penggunaanya dalam Pembuatan Ikan Tongkol (Euthynnus affinis) Asap, Sekolah Pasca Sarjana, Institut Pertanian Bogor, 2007.

[8] I. Nurrassyidin dan Zultiniar, Pengaruh Variasi Temperatur dan Waktu Terhadap Rendemen Pirolisis Limbah Kulit Durian Menjadi Asap Cair, Universitas Riau, 2015.

[9] J. L.Wang dan L.L. Wang, Catalytic Pyrolysis of Municipal Plastic Waste to Fuel with Nickel Loaded Silica-alumina Catalysts, Energy Sources, 33 : 1940-1948, 2011.

[10] J. Z. Lombok, B. Setiaji, Trisunaryanti dan K. Wijaya, Effect of Pyrolisis Temperature and Distillation On Character Of Coconut Shell Liquid Smoke, Asian Journal Of 
Science And Technology, 5 : 320-325, 2014.

[11] J. A. Maga, Smoke in Food Processing, CRC Press, Boca Ranton, Florida, 1-3 : 113-118, 1988.

[12] K. Tiilikkala, L. Fagernas, dan J. Tiilikkala, History And Use Of Wood Pyrolysis Liquids As Biocide and Plant Protection Product, The Open Agriculture Journal, 4 : 111-118, 2010.

[13] M. A. F. Mazlan, Y. Uemura, N. B. Osman, dan S. Yusup, Characterizations Of Biochar From Fast Pyrolysis Of Meranti Wood Sawdust, Journal Of Physics, Conference Series 622 (2015) 012054, 2015.

[14] M. Yatagai, M. Nishimoto, K.H.T. Ohira, dan A. Shibata, Termiticidal Activity of Wood Vinegar, Its Components and Their Homologues, J Wood Sci, 48 : 338-342, 2002.

[15] P. Darmaji, Aktivitas Antibakteri Asap Cair yang Diproduksi dari Bermacam-macam Limbah Pertanian, Laporan Penelitian Mandiri, DPP-UGM, 16:19-22, 1996.

[16] Padil dan Yelmida, Produksi Nitroselulosa Sebagai Bahan Baku Propelan Yang Berbasis Limbah Padat Sawit, Laporan Penelitian Hibah Penelitian Stranas Batch II, Universitas Riau, 2009.

[17] R. Rustam, R. Sulaeman, G. M. E Manurung dan Kausar, Pemanfaatan Limbah Kelapa Sawit Sebagai Bahan Baku Asap Cair (Cuka Kayu) Untuk Meningkatkan Kesejahteraan Petani Kebun Kelapa Sawiti, Universitas Riau, 2015.

[18] S.P.A. Anggraini dan S. Yuniningsih, Utilization of Various Types Of Agricultural Waste Became Liquid Smoke Using Pyrolisis Process, Chemical and Process Engineering Research, 28, 2014.

[19] X. Tong, H. Chen, J. Hu, Y. Bi, Z. Sun, dan W. Fan, The Efficient And Sustainable Pyrolysis And Gasification Of Biomass By Catalytic Processes, ChemBioEng, 2 : 119, 2014. 